division; and, also, laboratories for pharmaceutical purposes and agricultural chemistry.

From this sketch it will be gathered that the courses of instruction are not only well provided for as regards laboratory equipment, but are thoroughly suited to the requirements of the students in every subject included in the syllabus.

\section{SCIAGRAPHS OF BRITISH BATRACHIANS AND REPTILES.1}

$\mathrm{O}^{\mathrm{N}}$ May 5 last, Mr. G. A. Boulenger, F.R.S., reading a paper before the Zoological Society of London, on "Some little-known Batrachians from the Caucasus,"

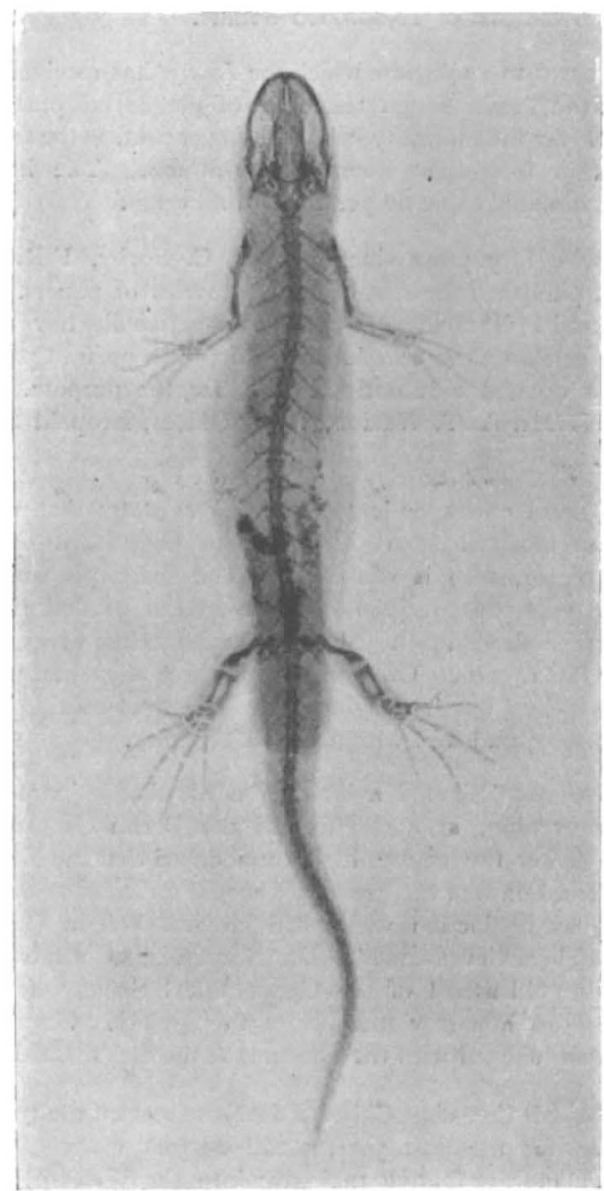

FIG. I.

announced (cf. P.Z.S., I896, p. 552) the first outcome of the application of the Röntgen rays to herpetological investigation, having by their aid settled the systematic position of a unique batrachian without injury to the specimen. The event aroused in the minds of Messrs. Green and Gardiner a determination to repeat the experiment on a larger scale, with the result now before usviz. a series of sciagraphs of all the British Batrachians and Reptiles, including the rare Smooth Snake (Coronella austriaca).

Two or three of the plates are indefinite, perhaps as

1 "Sciagraphs of British Batrachians and Reptiles." Thirteen plates mounted, with portfolio. By J. Green and J. H. Gardiner. (Wallington, Surrey, 1897.) With an introduction by (G. A. Boulenger, F.R.S.

NO. I 432 , VOL. 55$]$ the result of light printing, but the majority, for clearness and sharpness of definition, mark a very considerable advance upon anything of the kind yet published, and enable us the better to judge of the possibilities of the method as an aid to zoological and anatomical study. The plate of the Crested Newt (Fig. I), which we reproduce, is especially noteworthy in this respect, and for the clearness with which the ossific nuclei of the carpus and tarsus are recorded. In the case of bones which, like these, are well isolated, and of those which are rod-like and dense, the method leaves little to be desired for purposes of general study and orientatior. of parts. Where thin flat bones exist, however, detail is not recorded; and as concerning the cranium, to which this remark especially applies, the appearances

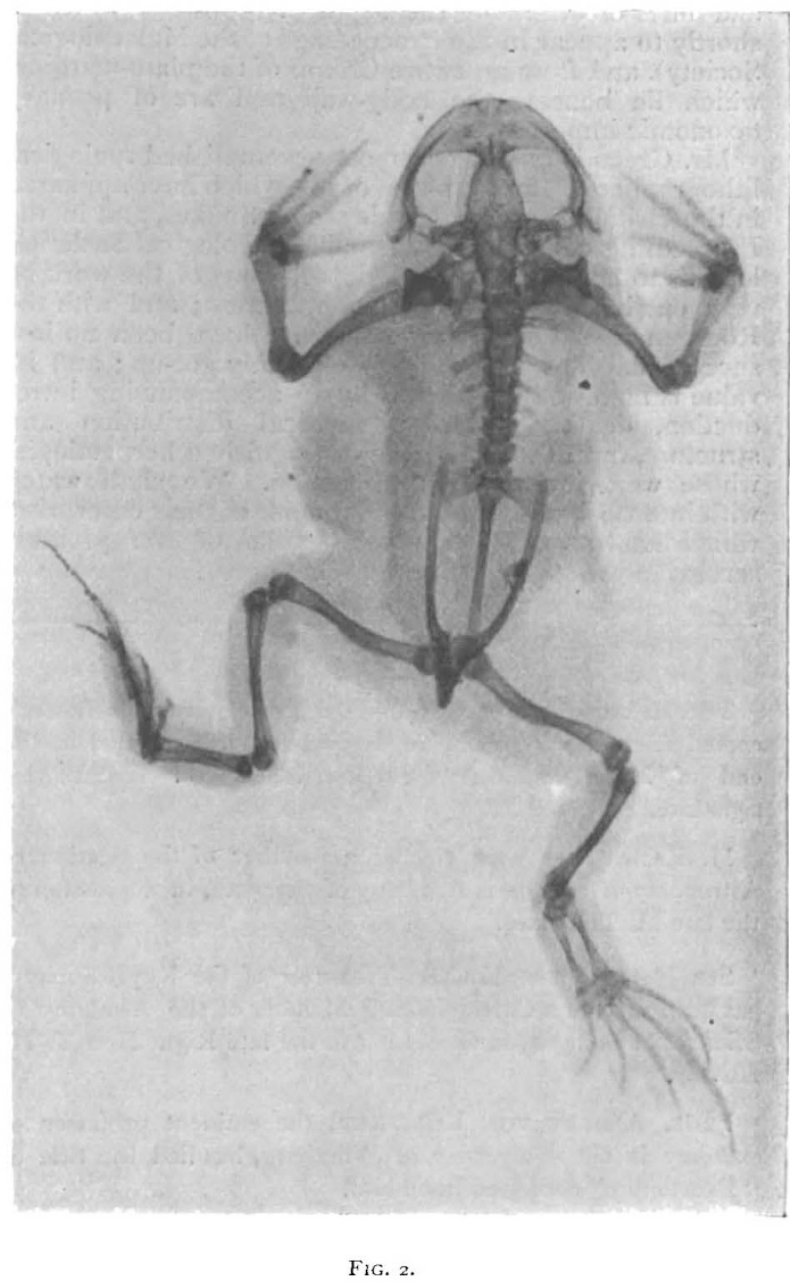

presented by some of the plates suggest delimitation of brain structure rather than anything that is osteological. Be this as it may, it is important to observe that marked indications of the soft parts occur in some of the prints-most conspicuously in the case of the large intestine, especially when fully laden with egesta largely composed of the elytra of beetles ingested as food. The area of overlap of the segments of the limbs and of not a few of the individual limb muscles is also rendered evident.

Detail is greatest in the figure of the Natterjack Toad, which we also reproduce (Fig. 2 ). Its lungs (like those of the frog of which a sciagraph by Messrs. Reid and Kuenen 
appeared in NATURE, vol. liii. p. 4I9) were unequally inflated. Not only can the texture of both of them be satisfactorily made out, but on the right side there is a uniformly tinted hemi-cardiac-shadow, indicative of the greatly thickened right lobe of the liver. Indications of the base of the stomach are also to be made out, and on both sides of the body there are feeble shadows at places coincident with the oviducts.

Messrs. Green and Gardiner have also favoured us with an advanced print of a sciagraph of a Pelodytes, which is in some respects sharper than those which they have placed on the market. They are continuing the work, and have recently exhibited before the Linnean and Malacological Societies sciagraphs of molluscs no less successful than those here under review-for they have obtained from the entire Nautilus a pictorial record of the muscle scars and lines of origin of the septa (a reprint of which is shortly to appear in the Proceedings of the Malacological Society), and from an entire Chiton of the plate-margins, which lie beneath the body-wall and are of primary taxonomic importance.

Mr. Green is one of our most accomplished zoological lithographers. Recent plates of his, which have appeared in the British Museum Catalogue of Snakes, and in the Proceedings of the Zoological and Malacological Societies, lead us to hope that in some departments of the work he may outrival his foreign contemporaries; and with the Röntgen rays he and his colleague have been no less successful. Their portfolio is elegantly got-up ; and its value is materially enhanced by an accompanying introduction, dealing with geographical distribution and structure, from the pen of the distinguished herpetologist whose work incited them to action. We shall watch with intense interest the development of their enterprise, which has already produced results of the greatest service to the student of animal life.

\section{NOTES}

TriE names of those who attended Prof. Sylvester's funeral, copied from the Times, were by inadvertence inserted at the end of Major MacMahon's article, instead of beneath his signature.

M. RADAU has been elected a member of the Section of Astronomy of the Paris Academy of Sciences, in succession to the late M. Tisserand.

Sir John Evans, K.C.B., Treasurer of the Royal Society, has been elected a Corresponding Member of the Academy of Sciences of Bologna, in succession to the late Right Hon. T. H. Huxley.

Prof. Albert von Kölliker, the eminent professor of anatomy in the University of Wirzburg, has had the title of "Excellency" conferred upon him.

DR. LAUDER BRUnTON, F.R.S., will give one of the general addresses at the forthcoming International Medical Congress in Moscow.

Prof. E. Ray Lankester, F.R.S., will preside over the meeting of the Museums Association, to be held at Oxford on July 7-9 of this year.

THE ninth meeting of the International Congress of Hygiene and Demography, which was to have been held at Madrid in October of the present year, has been postponed till April 1898.

Dr. H. E. Arustroxg, F.R.S., has been elected a member of the Athenæum Club, under the rule which empowers the annual election by the Committee of nine persons "of disNo. I 432 , VOI. 55$]$ tinguished eminence in science, literature, the arts, or for public services."

A Fine bronze statue of the late Sir Richard Owen has just been placed in the Natural History Museum, South Kensington, facing the statue of Darwin. The funds for the statue were raised by public subscription.

WE regret to have to record the death of Dr. G. A. Kenngott, for many years professor of mineralogy in the University of Zürich, and director of the mineralogical museum there.

A Revter's telegram from Ottawa says that the Canadian Government intends to begin immediately the works for enlarging and deepening the canal system in the Dominion, securing a uniform depth of 14 feet from Lake Superior to Montreal, at an estimated cost of 10,000,000 dollars.

ACCORDING to a telegram which the Lancet has received from Bombay, the Yersin serum treatment of plague has practically failed. So far the mortality has been $5^{\circ}$ per cent. in the selected cases within forty-eight hours of the attack. The hospital mortality is stated to be 60 per cent. in all cases.

IT is now fifty years since Dr. H. C. Sorby, F.R.S., of Sheffield, published the first of his long series of papers. The Literary and Philosophical Society of his native city have determined to celebrate the occasion by having his portrait painted, and have opened a subscription list for the purpose. The treasurer is Mr. A. T. Watson, Assay Offices, Leopold Street, Sheffield.

THE Ottawa correspondent of the Times states that reports have been received from Mr. William Ogilvie, a Government Surveyor, who is wintering on the Yukon, in which he speaks of gold discoveries on the tributaries of that river of almost incredible richness. Mr. Ogilvie has taken every means to verify the reports. On one stream three men had washed out I 200 dollars' worth in eight days. The gold-bearing belt is 300 miles long, and well within British territory.

Dr. Nansen delivered a lecture on his Arctic journey, on Saturday evening, at a meeting of the Berlin Geographical Society. After the lecture, it was announced that the Emperor had conferred on him the great gold medal for science and art, "the highest distinction which can be bestowed in Germany for peaceful achievements." Dr. Nansen also received the Humboldt gold medal of the Geographical Society, and was nominated an honorary member of the Society. On Sunday Dr. Nansen lunched with the Emperor at the Royal Castle.

The British Consul at Chicago, in his report on the trade in his district for the past year, mentions that many goods of German tnake are finding their way into the Western States, and are taking the place of British goods. Amongst these are chemicals, quinine, ammonia, caustic soda, plate-glass, fuller's earth, Portland cement, cutlery, needles, surgical instruments, paints, and oils.

Science makes a strong protest against some vexatious provisions in the new Tariff Bill now before Congress. The Bill imposes a tax of 45 per cent. ad valorem on scientific apparatus "imported especially for colleges and other institutions"; it imposes a tax of 25 per cent. on books imported for public libraries, on books "printed in languages other than English," on books "printed more than twenty years," and on books "devoted to original scientific research"; and it imposes a tax of 25 per cent. on worls of art. This simple statement shows that men of science in the United States have abundant cause for complaint against the Bill. 